\begin{tabular}{lc}
\hline SCIENCE \& TECHNOLOGY \\
Journal homepage: http://www.pertanika.upm.edu.my/ \\
\hline PERTANIKA
\end{tabular}

\title{
Public Tendering Practices, Issues and Directions - A Case of Pakistan Construction Sector
}

\author{
Ali Raza Khoso ${ }^{1 *}$, Md Aminah Yusof ${ }^{1}$, Muhammad Aslam Leghari², Fida Siddiqui ${ }^{3}$ \\ and Samiullah Sohu ${ }^{4}$ \\ ${ }^{1}$ Department of Structure and Materials, School of Civil Engineering, Faculty of Engineering, Universiti \\ Teknologi Malaysia, 81310 UTM, Johor Bahru, Malaysia \\ ${ }^{2}$ National Engineering Services Pakistan (NESPAK), Hyderabad, 71500, Pakistan \\ ${ }^{3}$ Department of Civil Engineering, Mehran University of Engineering \& Technology Jamshoro, 76062, Pakistan \\ ${ }^{4}$ Department of Civil Engineering, Quaid-e-Awam University of Engineering Science \& Technology, Larkana \\ Campus, 67480, Pakistan
}

\begin{abstract}
Outdated tendering system is a significant obstacle in the momentum of public sector development in Pakistan. This study aims to examine various undiscovered part of public tendering through a detailed survey from key professionals, experts, and decision-makers of public projects. Furthermore, research covers the present status of public tendering in Pakistan and provides recommendations as per experts' opinion. This paper exhaustively highlights how the classical customs of the public tendering in Pakistan could track the old-fashioned sector to an upright path. Intensive interviews and questionnaire surveys were carried out throughout the country for data compilation. The one-way ANOVA test was performed to verify the perception of various participants and to reject the null hypothesis. The study revealed various interesting facts of present-day situations of public tendering. Various pitfalls in public tendering were underlined in the speculation of experts. The study concluded that public tendering in Pakistan is crowded with severe threats that may be alarming for the future of the industry. Un-discovering of alarming facts about public

ARTICLE INFO

Article history:

Received: 22 July 2020

Accepted: 05 November 2020

Published: 22 January 2021

DOI: https://doi.org/10.47836/pjst.29.1.07

$\overline{\text { E-mail addresses: }}$

raza.ali@graduate.utm.my (Ali Raza Khoso)

tendering in Pakistan opens the directions for several researchers in terms of exploring project case studies further. The research is an eye-opener for policymakers, experts, decision-makers and governmental bodies to regulate the public tendering system accordingly.
\end{abstract} aminahyusof@utm.my (Md Aminah Yusof)

leghariaslam@gmail.com (Muhammad Aslam Leghari)

fida.siddiqui@faculty.muet.edu.pk (Fida Siddiqui)

sohoosamiullah@gmail.com (Samiullah Sohu)

* Corresponding author
Keywords: Contractor selection, current practices, Pakistan, public tendering, tendering issues 


\section{INTRODUCTION}

Public tendering principally integrates the fragmented supply of construction teams such as project managers, engineers, architects, contractors, suppliers and labourers. The public tendering encounters the challenges of right decision making which has predominant role in the construction project life cycle (Khoso \& Yusof, 2020). A typical tendering process normally follows an extensive process, for executing infrastructures in public projects, by embroiling the right construction team at the right time at the right place. A public sector is predominantly considered a larger employer because it engages in mega projects in any country. Comparing to the private sector counterpart, the leading sector of construction projects is a public sector in any country and so in Pakistan. According to the annual report (2014-2015) of Pakistan Public Procurement Regulatory Authority (PPRA), a total of 31,844 public tenders were profitably allocated to various contractors, thus making this sector the largest in the country (PPRA, 2015).

The public sector in Pakistan must abide by the government's laws and legal boundaries. These official acts sometimes negatively affect the progress of the sector and driving the sector into more convoluted nexus owing to large legal formalities and strict procedures. Kog and Yaman (2016) compared the private and public sectors and stated that the private sectors were less concerned about legal procedures and were more flexible towards the tendering processes. However, the public sector projects are relatively more complicated, possessing high social involvement, extremely strict rules, and legal boundaries, and having diverse nature of work, and involving an inflexible tendering process. Further, they demonstrated that the private sector clients are reluctant and follow their own developed tendering process, whereas, in the public sector owing to public accountability, the project bid price is a key concern. This is also confirmed by Jobling and Smith (2018) who agreed that there were different mandates for public sector compared to the private one especially in developing countries.

Traditionally, most of the time in the public sector the project is awarded to the lowest bidder (Cheaitou et al., 2019; Lo \& Yan, 2009). This lowest bid award scheme is a widespread practice in the competitive bidding system. Lo et al. (2007) believed that the competitive bidding system had been blamed for accepting abnormally low bids and also a prime cause of inferior quality in the projects. In contrast to the lowest bid award, the clients are more interested in exploring the best value for money along with the bid price. Ayoti (2012) stated that the tender which offered the best value for money would have to win the business in a public environment. This confrontation between the lowest price and the best value for money remained a debate for several years in the public construction history of many countries. Many researchers believe that the lowest bid award is one of the pillars of the best value for money strategy. On the contrary, several researchers agreed 
that this system would not guarantee the maximum output and causes serious problems (Cheaitou et al., 2019; Horat et al., 2013; Wong et al., 2000) and further creates unhealthy competition in the market.

Besides the aforementioned issue of the lowest bid scheme in public sector, an additional major obstacle and dilemma in the process is the right and competent contractor selection. The importance of appropriate contractor selection in public tendering can never be ignored as the successful delivery of project depends on the contractors (Khoso \& Yusof, 2020). Kog et al. (2014) believed that the choice of a capable contractor was one of the challenging decisions in the tendering process. Also, Jaskowski et al. (2009) stressed on precise assessment of the contractors through extensive evaluation. The precise decision entails that extensive qualification criteria must be designed for the selection. A research investigates that many issues in a project may have been due to the absence of suitable selection criteria consideration which allows selection of appropriate contractor (Elsayah, 2016). In public tendering apart from other goals, the client is expected to evaluate contractors based on several criteria other than bid price to ensure the capability of the contractors for the specific project and further to restrict the bidders at a later stage. But on account of several characteristics among contractors, the clients are tormented to select a contractor from a large pool of bidders (Liu et al., 2015). Therefore, an extensive evaluation of contractors in a public project leads to better decisions. Furthermore, in several cases, the correct information from contractor on quality criteria is not possible. Birjandi et al. (2019) pointed out that decision makers confront the issue of appropriate assessment owing to some vague criteria, and reliable information from contractors on criteria was problematic to collect. Wondimu et al. (2020) also confirmed that the contractor manipulated the information on certain criteria and presented the information according to their own advantages.

The issue of improper evaluation of contractors is prevailing globally. Traditionally, client sets excessive weight on price and lowers emphasis on soft parameters (Kadefors, 2005). This practice is more specific in public departments (Kumaraswamy \& Anvuur, 2008) and the relation between the price and other criteria is not perfectly understood. Thus, many researchers believe that the tendering process is very intricate, for example; $\mathrm{Ng}$ and Skitmore (2001) exclaimed that the process was multifaceted because of high technical and financial evaluation. Similarly, Watt et al. (2010) claimed the process was full of risk and entailed higher uncertainty while also Bochenek (2014) also favored the same claim. Furthermore, Hochstetter et al. (2004) observed numerous issues in tendering process and noted that high-level requirements from bidders, intricate evaluation process, extremely short deadlines to bidders, and less expected completion time for project delivery were some loopholes in a tendering system inherently. Liu et al. (2015) investigated the 
gaps in the tendering process and highlighted a number of problems as the root causes of tender complication. They included a very short deadline to deliver the project, distinct characteristics of bidders and diverse experience and knowledge of decision-makers in the tender evaluation.

Pertaining to the said problems, the tendering phase of the public projects is still encountering several serious issues and yet the right direction is still unclear especially in Pakistan where limited research is conducted to draw attention to this issue. This is consequently opening the gates for more research in this less discovered area. One such attempt is undertaken in this research in the form of unfolding serious reservations of professionals working in the public sector construction projects in Pakistan. The construction sector in Pakistan is advancing in optimistic directions but the industry unfortunately is not enjoying the expected positive outcome and reputation globally. Many researchers believed that shaky public tendering practices in Pakistan are key triggers of these issues. Farooqui et al. (2008) believed that in Pakistan public sector, the lowest bid award system was the most prevailing reason for poor performance in the country. Similarly, Khan and Khan (2015) asserted that the lowest bid award was a major reason for public sector downfall. Apart from the issue of the lowest bid, Maqsoom et al. (2014) stressed that poor public tendering policies were responsible for several mishaps in the public sector. Besides this, Azhar et al. (2008) mentioned that alongside other problems, the contract management and wrong bidding strategies in Pakistan are accountable for project issues. Looking at several shreds of evidence against the traditional public tendering practices, this study strives for the following research questions:

RQ1. What are the prevailing practices of public tendering in various organizations in Pakistan?

RQ2. What are the issues in public tendering traditional practices that impede the industry hike?

RQ3. How can the current loopholes in the traditional system be resolved?

This study aims to address the aforementioned research questions. This work is novel in many aspects as none of the past research has exhaustively addressed the issues of public tendering of Pakistan exhaustively until now. The studies of Farooqui et al. (2008) and Khan \& Khan (2015) are only master pieces of the works in the literature where authors concentrated on the lowest bid flaws in the system. Moreover, none of the research until now has yet comprehensively discussed the issues of public tendering except the ones targeting this lowest bid award. This study is a step beyond highlighting the current practices, and the earlier issues in the existing system, and exhaustively discussed the possible recommendation from the viewpoint of experts. 


\section{METHODS}

This research aims to investigate the current tendering practices and problems in Pakistan and their possible solutions. Inherent issues of public tendering were examined through a meticulous overview of literature around the globe. Facts of public tendering obtained through literature were discussed to justify the study for the Pakistan public sector. Not limited to this, the regularly published magazines, articles, and reports from various organizations in Pakistan were consistently reviewed. The explored organizations in Pakistan includes Pakistan Public Procurement Regulatory Authority (PPRA), Pakistan Bureau of Statistics (PBS), State Bank of Pakistan (SBP), and Pakistan Engineering Council (PEC). Furthermore, this study seeks to pursue exhaustive knowledge in the context of public tendering in Pakistan. In this connection, the expert surveys in the form of interviews were carried out with the key and top hierarchy experts in various public and private organizations in Pakistan. Such studies rely on shared perspectives from different groups of people such as clients, consultants and contractors as suggested by (Murtagh \& Brooks, 2019). For this present research, an expert sampling technique of purposive sampling method was adopted. Fundamentally, this was a non-probabilistic sampling approach which is mutually based on the population characteristics and the study objectives. The high-profile decision makers and policy makers from client, consultants and contractors participated in present study. A special focus was kept on the experts in public organizations those having rich experience in public tendering.

To meet the intended research goals, issues of public tendering in Pakistan were presented in a pilot survey. The pilot survey was basically conducted to verify the viability of the study before the actual data collection process on a large sample size. Melody (2008) defined a pilot study as an informal way on a handful of participants to validate the studies. The shared groups of experts further pointed out the local prevailing problems of the industry apart from those mostly cited in the literature. An exhaustive survey instrument was designed in two different sections for the intention of achieving the significant outcomes of this research. The first section comprises the current practices and problems of Pakistan public tendering whereas, the later part is reserved for the possible opinion of experts on the current situation of public tendering in the form of possible solutions. The instrument was thus prepared and distributed to pertinent professionals working in public projects and especially with the experts those deal with the tendering matters. Collected responses were analyzed in SPSS and later kept under discussion with the experts. The differences of opinion of all respondents' group (i.e., client, consultants, and contractors) were investigated by computing a one-way ANOVA test. Henceforth a hypothesis is developed as follows.

$\mathrm{H}_{1}$ : There is a substantial difference in the perception of each group on current practices, issues, and recommendations provided by experts on public tendering.

The research method flow is illustrated further in Figure 1 for further reference. 


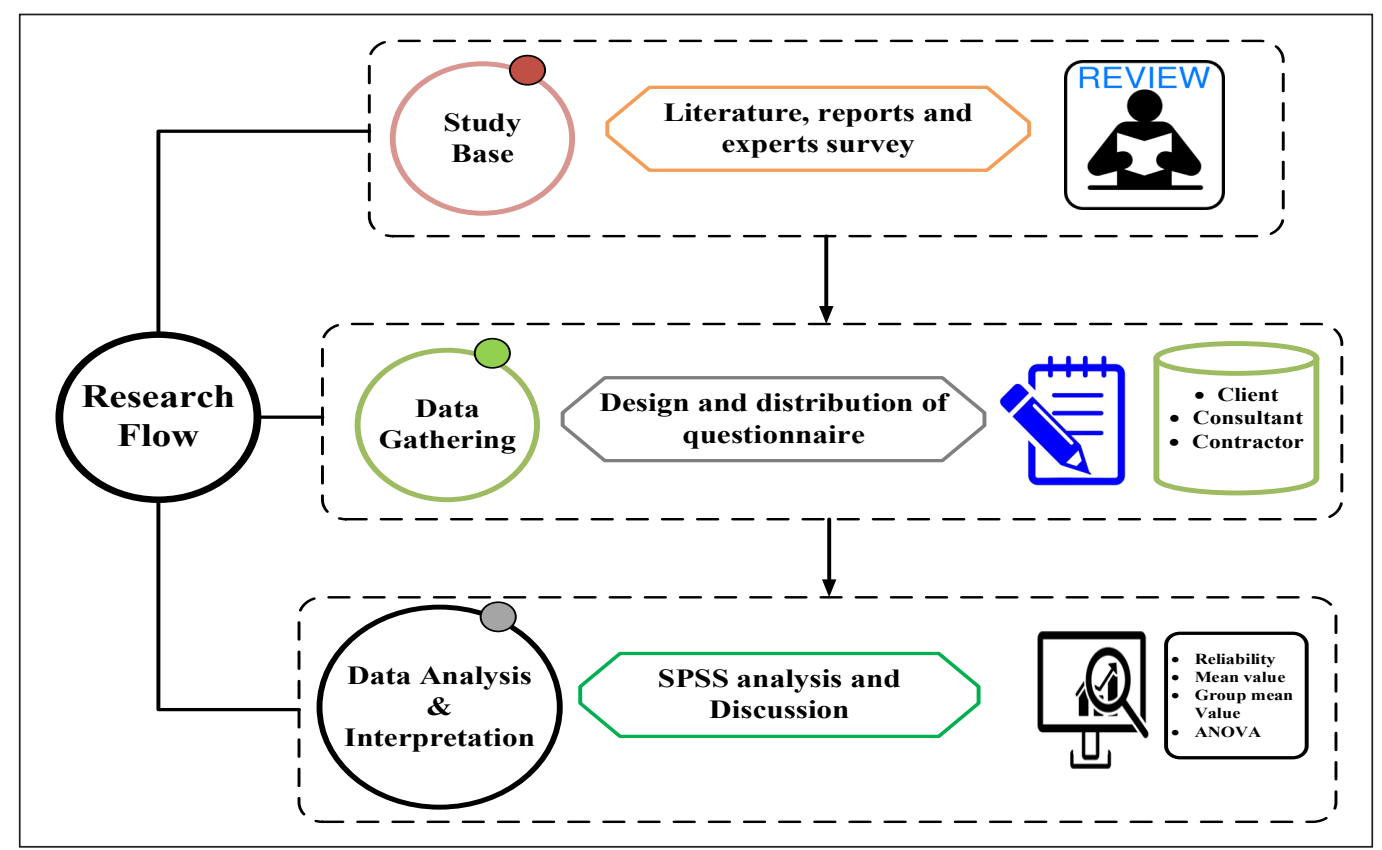

Figure 1. Research method flow diagram

\section{Data Collection and Analysis Method}

Data collection on a larger sample size begins after the successful completion of the pilot study. The data collection process involved various experienced participants from different groups i.e. client, consultants and contractors. Melody (2008) suggested that the opinion with the relevant participants based on their experience was sufficient for investigating the procedures and method. Before commencing with data collection, the targeted organizations are listed out from various public sector organizations in Pakistan. To ensure the participation of highly credible and pertinent respondents, vastly experienced professionals are approached in the data collection stage. The sample size was confirmed from the study of Morenikeji (2006). According to this study, below 30 respondents are deemed small size, while above 30 is viewed as a larger sample. However, to receive a high response from participant is also another problem. Wahlberg and Poom (2015) believed that all kinds of survey research where human participants were involved, the response rate of the questionnaire was relatively low, and researchers were often reliant on the respondents. Fortunately for this study, 109 responses were gathered from different provinces (states) and regions of the country. The demographic information of survey respondents is illustrated in Table 1.

Table 1 demonstrates that public sector clients are mostly targeted in the survey. Furthermore, the quality of respondents can be depicted from the high-level experience of respondents. According to the frequency analysis of respondents, over $50 \%$ of respondents 
Table 1

Demographic information of survey respondents

\begin{tabular}{|c|c|c|c|c|c|c|}
\hline Data types & & & No. of respond & ents & & \\
\hline & Public & Private & Semi-Public & NGO/INGO & & \\
\hline $\begin{array}{l}\text { Ownerships of } \\
\text { respondents }\end{array}$ & 53 & 42 & 8 & 6 & & \\
\hline & Client & Consultant & Contractors & & & \\
\hline 1уре of organization & 58 & 23 & 28 & & & \\
\hline Experience in & $1-5$ yrs. & $6-10$ yrs. & $11-15$ yrs. & Above 15 yrs. & & \\
\hline Construction sector & 37 & 17 & 17 & 38 & & \\
\hline $\begin{array}{l}\text { Experience in public } \\
\text { tendering }\end{array}$ & 46 & 26 & 12 & 25 & & \\
\hline Firm's Geographical & Sindh & Punjab & KPK & Baluchistan & $\begin{array}{l}\text { Gilgit \& } \\
\text { AJK }\end{array}$ & \\
\hline Location & 70 & 7 & 5 & 18 & 3 & \\
\hline $\begin{array}{l}\text { Position of } \\
\text { respondents }\end{array}$ & $\begin{array}{l}\text { Project } \\
\text { Manager }\end{array}$ & $\begin{array}{l}\text { Assistant/ } \\
\text { Executive } \\
\text { Engineer }\end{array}$ & $\begin{array}{c}\text { Chief Executive } \\
\text { Officer }\end{array}$ & $\begin{array}{c}\text { Procurement/ } \\
\text { Contract } \\
\text { Engineer }\end{array}$ & $\begin{array}{l}\text { Project } \\
\text { Director }\end{array}$ & others \\
\hline & 8 & 47 & 15 & 13 & 5 & 21 \\
\hline Highest Educational & Diploma & Bachelor & Masters/M.Phil. & & & \\
\hline Level & 1 & 59 & 49 & & & \\
\hline
\end{tabular}

have above ten years' experience in the construction. Furthermore, around 34\% of respondents have similar experience in public tendering which is a reasonably significant number. The position of respondents further witnesses the quality of the data sample. As discussed earlier, top hierarchy personnel from the various organizations in Pakistan were pursued.

Survey responses were gathered on a five-point level of agreement and disagreement scale, where 1 represents strongly disagree and 5 represents strongly agree. An undecided option was also offered on the scale for those participants who have no information on particular question. SPSS (Statistical Packages for Social Sciences) was employed for the data analysis where reliability analysis, mean values and group mean values are supported to validate the responses. The mean value in the form of Average Index (AI) equal and greater than 3 was considered as benchmark and any value above 3 is recognized in the category of agree and strongly agree as per (Kim et al., 2018). Furthermore, the one-way ANOVA test was performed to cross-check the perception of client, consultant, and contractor on different issues and current situations of public tendering in the country. Therefore, the ANOVA test was presented to validate that there was no major difference in the opinion of all stakeholders on raised concerns. This test was verified at a $5 \%$ level of significance i.e. significant value of any case lesser than $5 \%$ (i.e., $>0.05$ ) was considered a divergence in the opinion of stakeholders ( $\mathrm{Ng}$ et al., 2009). 


\section{RESULTS AND DISCUSSION}

\section{Data Reliability}

The reliability of data sample depends on the internal measures of reliability (Wang et al., 2019). To validate the quality of data, Cronbach's alpha test was carried out in SPSS. The Cronbach's alpha values lay between 0 to 1 , where the value of 0.7 was considered the basis for the internal consistency, and 0.6 was also considered satisfactory (Phogat \& Gupta, 2019). For this data sample, 0.783 value was found for the first section of questionnaire and 0.889 for the second part. Henceforth, the data sample was quite satisfactory for conducting a scientific research.

\section{Analysis and Discussion on Current Practices of Public Tendering in Pakistan}

In the first part of the study, multiple questions were raised in connection to current practices in various organizations of the public sector in Pakistan alongside with prevalent issues associated with current practices. A one-way ANOVA test was performed to examine the significant values of the responses. The results reveals that there was no significant difference in the majority of arguments except for two questions namely, "sometimes contractors provide wrong information on given criteria to client" and "public client accepts the abnormally low bid from contractors" with sig. values of $0.001(<0.05)$ and $0.012(<0.05)$ respectively. The one-way ANOVA test results confirmed that the null hypothesis $\left(\mathrm{H}_{0}\right)$ was rejected on the majority of arguments. However, a small difference in the opinion of participants' groups was observed in the said arguments. Owing to the opinion differences, a post hoc test was performed in SPSS using Tukey's test to detect which group haddifferent opinions, among others.

Analysis of the post hoc test revealed that there was a disagreement of opinion between client and contractor on both said arguments. To explore this further, the group mean values of both cases from clients and contractors could be referred (Table 2). According to the obtained mean values, the client's group is more inclined toward the opinion that the contractor provides wrong information to them, but the contractor's group rejects the argument. However, the case is different in the second query as per the opinion of both participant groups. Therefore, no large difference in the opinion is observed for this case. Further discussion on the obtained results is discussed below.

A contractor is a key stakeholder in the construction industry and his/her role in the successful delivery of a project can never be ignored. Analysis of survey shows that the currently nature of construction projects is turning out to be complicated in Pakistan owing to several reasons such as market demands in the form of innovative designs, construction methods and modern skills. Such challenges are the impediment to a successful delivery of a project. Looking at these challenges, a client ought to focus on the selection of a 
Table 2

Total mean value and group mean value results of current practices of public tendering in Pakistan

\begin{tabular}{|c|c|c|c|c|}
\hline Questions/Arguments & & $\mathrm{N}$ & Mean & Std. Deviation \\
\hline \multirow{4}{*}{$\begin{array}{l}\text { The nature of construction projects in } \\
\text { Pakistan is becoming more complicated. }\end{array}$} & Client & 58 & 3.50 & 1.158 \\
\hline & Consultant & 23 & 3.48 & 0.790 \\
\hline & Contractor & 28 & 3.50 & 0.839 \\
\hline & Total & 109 & 3.50 & 1.006 \\
\hline \multirow{4}{*}{$\begin{array}{l}\text { The contractors need to be more capable } \\
\text { of meeting the demand for complicated } \\
\text { projects. }\end{array}$} & Client & 58 & 4.28 & 0.854 \\
\hline & Consultant & 23 & 4.30 & 0.470 \\
\hline & Contractor & 28 & 3.96 & 0.693 \\
\hline & Total & 109 & 4.20 & 0.755 \\
\hline \multirow{4}{*}{$\begin{array}{l}\text { Public organizations are bound to follow } \\
\text { strict legal process and formalities in } \\
\text { tendering and procurement. }\end{array}$} & Client & 58 & 4.45 & 0.680 \\
\hline & Consultant & 23 & 4.30 & 0.876 \\
\hline & Contractor & 28 & 4.18 & 0.772 \\
\hline & Total & 109 & 4.35 & 0.750 \\
\hline \multirow{4}{*}{$\begin{array}{l}\text { Public organization follows PPRA rules/ } \\
\text { guidelines in tendering. }\end{array}$} & Client & 58 & 4.43 & 0.920 \\
\hline & Consultant & 23 & 4.48 & 0.593 \\
\hline & Contractor & 28 & 4.18 & 0.905 \\
\hline & Total & 109 & 4.38 & 0.858 \\
\hline \multirow{4}{*}{$\begin{array}{l}\text { Public organizations follow their own } \\
\text { developed rules or process in tendering. }\end{array}$} & Client & 58 & 2.97 & 1.401 \\
\hline & Consultant & 23 & 2.83 & 0.984 \\
\hline & Contractor & 28 & 2.61 & 1.066 \\
\hline & Total & 109 & 2.84 & 1.241 \\
\hline \multirow{4}{*}{$\begin{array}{l}\text { Public organizations assess contractors } \\
\text { based on the following evaluation criteria } \\
\text { during the prequalification stage. a) } \\
\text { Experience }\end{array}$} & Client & 58 & 4.50 & 0.755 \\
\hline & Consultant & 23 & 4.57 & 0.507 \\
\hline & Contractor & 28 & 4.46 & 0.793 \\
\hline & Total & 109 & 4.50 & 0.715 \\
\hline \multirow{4}{*}{$\begin{array}{l}\text { Public organizations assess contractors } \\
\text { based on the following evaluation criteria } \\
\text { during the prequalification stage. b) } \\
\text { Financial Soundness }\end{array}$} & Client & 58 & 4.45 & 0.776 \\
\hline & Consultant & 23 & 4.52 & 0.511 \\
\hline & Contractor & 28 & 4.57 & 0.504 \\
\hline & Total & 109 & 4.50 & 0.661 \\
\hline \multirow{4}{*}{$\begin{array}{l}\text { Public organizations assess contractors } \\
\text { based on the following evaluation criteria } \\
\text { during the prequalification stage. c) } \\
\text { Technical Personnel }\end{array}$} & Client & 58 & 4.41 & 0.795 \\
\hline & Consultant & 23 & 4.52 & 0.593 \\
\hline & Contractor & 28 & 4.57 & 0.504 \\
\hline & Total & 109 & 4.48 & 0.688 \\
\hline \multirow{4}{*}{$\begin{array}{l}\text { Public organizations assess contractors } \\
\text { based on the following evaluation criteria } \\
\text { during the prequalification stage. d) } \\
\text { Equipment }\end{array}$} & Client & 58 & 4.24 & 0.904 \\
\hline & Consultant & 23 & 4.26 & 0.619 \\
\hline & Contractor & 28 & 4.57 & 0.690 \\
\hline & Total & 109 & 4.33 & 0.806 \\
\hline \multirow{4}{*}{$\begin{array}{l}\text { Public organizations assess contractors } \\
\text { based on the following evaluation criteria } \\
\text { during the prequalification stage. e) } \\
\text { Management Capability }\end{array}$} & Client & 58 & 4.00 & 0.991 \\
\hline & Consultant & 23 & 4.30 & 0.765 \\
\hline & Contractor & 28 & 4.25 & 0.844 \\
\hline & Total & 109 & 4.13 & 0.914 \\
\hline
\end{tabular}


Table 2 (continue)

\begin{tabular}{|c|c|c|c|c|}
\hline Questions/Arguments & & $\mathrm{N}$ & Mean & Std. Deviation \\
\hline \multirow{4}{*}{$\begin{array}{l}\text { Public organizations assess contractors } \\
\text { based on the following evaluation criteria } \\
\text { during the prequalification stage. f) Quality }\end{array}$} & Client & 58 & 4.03 & 1.008 \\
\hline & Consultant & 23 & 4.35 & 0.573 \\
\hline & Contractor & 28 & 4.04 & 1.036 \\
\hline & Total & 109 & 4.10 & 0.942 \\
\hline \multirow{4}{*}{$\begin{array}{l}\text { Public organizations assess contractors } \\
\text { based on the following evaluation criteria } \\
\text { during the prequalification stage. g) Health } \\
\& \text { Safety }\end{array}$} & Client & 58 & 3.57 & 1.110 \\
\hline & Consultant & 23 & 3.96 & 0.638 \\
\hline & Contractor & 28 & 3.61 & 0.994 \\
\hline & Total & 109 & 3.66 & 1.002 \\
\hline \multirow{4}{*}{$\begin{array}{l}\text { Contractor's evaluation criteria in public } \\
\text { organization are not sufficient. }\end{array}$} & Client & 58 & 3.93 & 0.915 \\
\hline & Consultant & 23 & 3.70 & 1.020 \\
\hline & Contractor & 28 & 3.57 & 0.959 \\
\hline & Total & 109 & 3.79 & 0.953 \\
\hline \multirow{4}{*}{$\begin{array}{l}\text { Clients evaluate contractors on certain } \\
\text { criteria where right data/information from } \\
\text { the contractor is not obtained. }\end{array}$} & Client & 58 & 3.79 & 1.120 \\
\hline & Consultant & 23 & 3.74 & 0.752 \\
\hline & Contractor & 28 & 3.71 & 0.810 \\
\hline & Total & 109 & 3.76 & 0.971 \\
\hline \multirow{4}{*}{$\begin{array}{l}\text { Sometimes contractors provide wrong } \\
\text { information on given criteria to clients. }\end{array}$} & Client & 58 & 4.19 & 0.888 \\
\hline & Consultant & 23 & 3.96 & 0.475 \\
\hline & Contractor & 28 & 3.50 & 0.793 \\
\hline & Total & 109 & 3.96 & 0.838 \\
\hline \multirow{4}{*}{$\begin{array}{l}\text { All contractor passing the threshold marks } \\
\text { are treated equally during the bid price stage } \\
\text { in public tendering. }\end{array}$} & Client & 58 & 3.83 & 1.157 \\
\hline & Consultant & 23 & 3.83 & 0.937 \\
\hline & Contractor & 28 & 3.89 & 0.497 \\
\hline & Total & 109 & 3.84 & 0.973 \\
\hline \multirow{4}{*}{$\begin{array}{l}\text { Your organization select contractors; a) that } \\
\text { offers least bid price but responsive }\end{array}$} & Client & 58 & 4.16 & 1.225 \\
\hline & Consultant & 23 & 4.39 & 0.722 \\
\hline & Contractor & 28 & 4.46 & 0.922 \\
\hline & Total & 109 & 4.28 & 1.064 \\
\hline \multirow{4}{*}{$\begin{array}{l}\text { b) without considering bid price only } \\
\text { qualification criteria-based }\end{array}$} & Client & 58 & 2.22 & 0.974 \\
\hline & Consultant & 23 & 2.17 & 1.154 \\
\hline & Contractor & 28 & 1.82 & 0.945 \\
\hline & Total & 109 & 2.11 & 1.012 \\
\hline \multirow{4}{*}{$\begin{array}{l}\text { c) based on weightage of technical and } \\
\text { price bid by considering multiple criteria } \\
\text { selection }\end{array}$} & Client & 58 & 3.38 & 1.240 \\
\hline & Consultant & 23 & 3.83 & 0.834 \\
\hline & Contractor & 28 & 3.82 & 0.819 \\
\hline & Total & 109 & 3.59 & 1.082 \\
\hline \multirow{4}{*}{$\begin{array}{l}\text { Special consideration in assigning threshold } \\
\text { (minimum passing marks) during the } \\
\text { prequalification stage is not made in public } \\
\text { tendering. }\end{array}$} & Client & 58 & 3.17 & 1.286 \\
\hline & Consultant & 23 & 3.17 & 0.887 \\
\hline & Contractor & 28 & 3.46 & 0.881 \\
\hline & Total & 109 & 3.25 & 1.115 \\
\hline
\end{tabular}


Table 2 (continue)

\begin{tabular}{|c|c|c|c|c|}
\hline Questions/Arguments & & $\mathrm{N}$ & Mean & Std. Deviation \\
\hline \multirow{4}{*}{$\begin{array}{l}\text { Public clients accept the abnormally low bid } \\
\text { from contractors. }\end{array}$} & Client & 58 & 3.09 & 1.315 \\
\hline & Consultant & 23 & 3.70 & 0.765 \\
\hline & Contractor & 28 & 3.75 & 0.752 \\
\hline & Total & 109 & 3.39 & 1.130 \\
\hline \multirow{4}{*}{$\begin{array}{l}\text { Tender is always awarded to one who } \\
\text { quotes lesser than ceiling price (estimation } \\
\text { by client). }\end{array}$} & Client & 58 & 3.38 & 1.309 \\
\hline & Consultant & 23 & 3.61 & 0.988 \\
\hline & Contractor & 28 & 3.89 & 0.737 \\
\hline & Total & 109 & 3.56 & 1.134 \\
\hline \multirow{4}{*}{$\begin{array}{l}\text { Traditionally, the final contract award is } \\
\text { made on the lowest cost basis. }\end{array}$} & Client & 58 & 3.98 & 1.116 \\
\hline & Consultant & 23 & 4.00 & 0.674 \\
\hline & Contractor & 28 & 4.29 & 0.460 \\
\hline & Total & 109 & 4.06 & 0.905 \\
\hline \multirow{4}{*}{$\begin{array}{l}\text { In your organization, contractors are } \\
\text { rejected on the consent of high officials. }\end{array}$} & Client & 58 & 2.74 & 1.117 \\
\hline & Consultant & 23 & 2.78 & 1.166 \\
\hline & Contractor & 28 & 3.25 & 1.041 \\
\hline & Total & 109 & 2.88 & 1.120 \\
\hline \multirow{4}{*}{$\begin{array}{l}\text { Your organization follows a decision- } \\
\text { making system for assessing the contractors. }\end{array}$} & Client & 58 & 2.69 & 1.301 \\
\hline & Consultant & 23 & 3.22 & 1.166 \\
\hline & Contractor & 28 & 2.43 & 1.230 \\
\hline & Total & 109 & 2.73 & 1.274 \\
\hline
\end{tabular}

capable contractor in its team. The availability of capable contractors can be ensured when an exhaustive assessment from contractor is made possible during the public tendering process. Therefore, the extensive and exhaustive selection of a contractor is a key to a successful project outcome.

According to the survey results, the current tendering system in Pakistan for the contractor's assessment, evaluation, and final selection is ambiguous and inconsistent in many aspects. Clients in the construction sector of Pakistan throughout the country strictly follow PPRA 2004 rules. These regulations restrict the public clients in many situations such as in quotation of the bid price. Nevertheless, some limited organizations are developing the system with their own modification in PPRA 2004 regulations despite the strict requirements in the legislation. Discussing the facts with experts revealed loopholes in implementation of the governmental regulations. A similar claim was made by Ibrahim et al. (2017) that in the developing countries, public regulations were sometimes modified due to weakness in the system.

Further analysis on current evaluation criteria revealed that Experience, Financial Soundness, Technical Personnel, Equipment, Management Capability, Quality and Health $\&$ Safety criteria are considered currently in evaluating or pre-qualifying the contractors in 
Pakistan. The survey also focused on associated issues with traditional quality criteria set by governmental bodies. Experts in Pakistan believe that these contractor selection criteria are outdated and furthermore not extensive enough to qualify a capable contractor especially in today's construction when the industry is changed at three sixty degrees. The matter is further worsened by the incorrect information provided by the contractor when asked for the available sources in the form of selection criteria. From the analysis of results, it is found that clients in the public sector in Pakistan are confronting the issue of receiving incorrect information from the contractors. This issue is prevailing because of inappropriate design of criteria by the client. In many cases, the right information from contractors on certain criteria is difficult to gather which creates problems in their true analyses.

While investigating the current selection mechanism in the country, the most adopted method is found as the least, and responsive price bid-based selection followed by weightage consideration of price and quality criteria. The survey further unwrap that the quality-based method is infrequent in public organizations. From the survey analysis, it is confirmed that in Pakistan, the least bid price mechanism is most common and many times abnormally bids are also considered for the award which is a great threat and further leads to project failure in many cases. Several reservations and differences of opinion were observed in the analysis. Despite the rules as per the PPRA 2004 which prohibits the acceptance of abnormal bid, it is still a common practice in the country which has adverse consequences. It is also evident from the results that the contract winner is always the one who quotes a bid lesser than estimation by the client. This method is followed by weightage consideration of price and quality where the weightages are measured based on a certain threshold values set by the client. Clients will normally set this number in the initial stage of preparation of tender documents. Some guidelines in Pakistan i.e. PEC suggests different values of these threshold marks for pre-qualifying the contractor such as 60 or 70 (out of 100). However, clients have further privilege to choose these marks reliant on the type of project within prescribed boundaries. The contractors attaining the threshold are qualified to bid for the project at the final stage. To unveil the current situation in Pakistan, a few questions were included in the questionnaire related to threshold marks. Results of the survey analysis found that in Pakistan, all the contractors attaining the threshold limit are considered equivalent and have equal opportunity to win the project. Even a contractor A with the highest marks for example, 95 , is treated equally to a contractor B having marks, for example, 70. This basically reflects that qualification mark is irrelevant as long as they are passing threshold. Thus, there is no further importance of prequalification criteria and multi-characteristic qualities among the contractors. Henceforth, the process of public tendering in Pakistan is a discontinuous progression that partially recognizes the importance of quality criteria.

While investigating the availability of the decision-making system and their application in the public sector, a discouraging response in the form of unavailability of such a system 
is obtained. Clients assign the responsibility of assessing the bids to a small group of experts who have the right to select or reject the competitors based on certain conditions. However, the entire judgement is based on a paperwork without any justified system or decision-making mechanism. Henceforth, there emerge chances of unjustified and unequal assessments on all cases as a result of human error. The aforementioned section unveils the current practices and relevant issues in public tendering in Pakistan which later help in developing the theoretical outcome from this research.

\section{Analysis on Opinion of Construction Industry Experts on Current Tendering Issues in Pakistan}

This section underlines the analysis and discussion part on the experts' opinion over the current practices in public tendering presently. Additionally, the section also covers various solutions for the prevailing issues in public sector in Pakistan. A significant number of questions and proposed solutions are enlisted in the 2 nd part of the questionnaire. The gathered data was analyzed in SPSS using mean values, group mean values and standard deviation (Table 3).

A one-way ANOVA test was also performed to verify the significant values of each variable. The result presents that there was no significant difference in majority of interrogations, except the two namely; “contractor's assessment process could be improved if the benefits of prequalification (PQ) phase is provided in the final contract award" and "the human-based assessment system causing problem in contractor's selection process" with respective sig. value of $0.007(<0.05)$ and $0.017(<0.05)$. From the sig. values of the cases, the one-way ANOVA test confirmed that the null hypothesis (H0) was rejected on the majority of suggestions. Due to the identified variations in opinion from different groups, a post hoc test was performed in SPSS. Analysis of post hoc test results uncovered that there was a significant difference in the opinion of consultants compared to other groups (i.e., client and contractor) on the first suggestion. Moreover, on the second query, the contractor's viewpoint was much different from the other two groups. The consultant was unwilling to accept suggestions in the first question. However, in the second question, the contractors' viewpoint was much different than the clients and consultants which clarified that contractors had more issues with the human-based assessment system of the public client. To explore further, the group mean values of both questions from clients and contractors were referred to. According to the group mean value, all groups of respondents agreed with both recommendations. The higher mean value (above 3 ) further indicated the validity of queries. The survey results on the opinion and recommendations of experts over the present condition in public sector in Pakistan is discussed below.

The survey result reveal that nowadays construction projects are of a complicated nature in Pakistan and the assessment of contractors is still based on earlier concepts. This further 
Table 3

Total mean and group mean value analysis results of opinion of construction industry experts on current tendering issues in Pakistan

\begin{tabular}{|c|c|c|c|c|}
\hline Suggestions & Type of respondents & $\mathrm{N}$ & Mean & Std. Deviation \\
\hline \multirow{4}{*}{$\begin{array}{l}\text { The nature of construction projects } \\
\text { nowadays requires extensive contractor's } \\
\text { assessment in meeting project demands. }\end{array}$} & Client & 58 & 4.28 & 0.523 \\
\hline & Consultant & 23 & 4.17 & 0.834 \\
\hline & Contractor & 28 & 3.93 & 0.858 \\
\hline & Total & 109 & 4.17 & 0.701 \\
\hline \multirow{4}{*}{$\begin{array}{l}\text { The success of a project is greatly } \\
\text { depending on the capability of a } \\
\text { contractor. }\end{array}$} & Client & 58 & 4.28 & 0.720 \\
\hline & Consultant & 23 & 4.48 & 0.593 \\
\hline & Contractor & 28 & 4.25 & 0.518 \\
\hline & Total & 109 & 4.31 & 0.648 \\
\hline \multirow{4}{*}{$\begin{array}{l}\text { A contractor is more responsible for } \\
\text { project success than other parties, for } \\
\text { instance, client and consultant. }\end{array}$} & Client & 58 & 3.93 & 1.090 \\
\hline & Consultant & 23 & 3.96 & 0.976 \\
\hline & Contractor & 28 & 4.39 & 0.832 \\
\hline & Total & 109 & 4.06 & 1.017 \\
\hline \multirow{4}{*}{$\begin{array}{l}\text { Public projects fail because of selecting } \\
\text { incapable contractors. }\end{array}$} & Client & 58 & 4.09 & 0.978 \\
\hline & Consultant & 23 & 3.96 & 1.065 \\
\hline & Contractor & 28 & 4.32 & 0.819 \\
\hline & Total & 109 & 4.12 & 0.960 \\
\hline \multirow{4}{*}{$\begin{array}{l}\text { Right contractor selection is still a } \\
\text { problem in public projects. }\end{array}$} & Client & 58 & 4.07 & 1.024 \\
\hline & Consultant & 23 & 4.00 & 0.953 \\
\hline & Contractor & 28 & 4.21 & 0.738 \\
\hline & Total & 109 & 4.09 & 0.938 \\
\hline \multirow{4}{*}{$\begin{array}{l}\text { The ultimate solution to public projects } \\
\text { lies in the proper selection of capable } \\
\text { contractors. }\end{array}$} & Client & 58 & 4.21 & 0.894 \\
\hline & Consultant & 23 & 4.04 & 0.638 \\
\hline & Contractor & 28 & 4.21 & 0.917 \\
\hline & Total & 109 & 4.17 & 0.848 \\
\hline \multirow{4}{*}{$\begin{array}{l}\text { In comparison to the private sector, } \\
\text { public organizations have more } \\
\text { complicated tendering process owing to } \\
\text { legal boundaries. }\end{array}$} & Client & 58 & 4.00 & 1.170 \\
\hline & Consultant & 23 & 4.00 & 0.674 \\
\hline & Contractor & 28 & 4.04 & 1.071 \\
\hline & Total & 109 & 4.01 & 1.050 \\
\hline \multirow{4}{*}{$\begin{array}{l}\text { The multi-characteristic requirement } \\
\text { from contractors is making the tendering } \\
\text { process more complicated. }\end{array}$} & Client & 58 & 3.60 & 1.337 \\
\hline & Consultant & 23 & 3.87 & 0.869 \\
\hline & Contractor & 28 & 3.89 & 0.956 \\
\hline & Total & 109 & 3.73 & 1.160 \\
\hline \multirow{4}{*}{$\begin{array}{l}\text { Flaws in evaluation process in public } \\
\text { tendering are responsible for projects' } \\
\text { failure in Pakistan. }\end{array}$} & Client & 58 & 3.88 & 1.215 \\
\hline & Consultant & 23 & 4.09 & 0.900 \\
\hline & Contractor & 28 & 3.86 & 0.803 \\
\hline & Total & 109 & 3.92 & 1.055 \\
\hline \multirow{4}{*}{$\begin{array}{l}\text { In your opinion which can be a reason for } \\
\text { project failure in Pakistan in the context } \\
\text { of public tendering? a) Lowest bid price } \\
\text { selection }\end{array}$} & Client & 58 & 4.36 & 0.873 \\
\hline & Consultant & 22 & 4.36 & 0.790 \\
\hline & Contractor & 28 & 4.29 & 1.013 \\
\hline & Total & 108 & 4.34 & 0.888 \\
\hline
\end{tabular}


Table 3 (continue)

\begin{tabular}{|c|c|c|c|c|}
\hline Suggestions & Type of respondents & $\mathrm{N}$ & Mean & Std. Deviation \\
\hline \multirow{4}{*}{$\begin{array}{l}\text { b) Insufficient contractor's technical } \\
\text { evaluation }\end{array}$} & Client & 58 & 4.26 & 0.890 \\
\hline & Consultant & 23 & 4.17 & 0.491 \\
\hline & Contractor & 28 & 4.29 & 0.763 \\
\hline & Total & 109 & 4.25 & 0.784 \\
\hline \multirow{4}{*}{$\begin{array}{l}\text { c) Poor weightage consideration of } \\
\text { technical and bid price criteria }\end{array}$} & Client & 58 & 4.02 & 0.982 \\
\hline & Consultant & 22 & 4.00 & 0.617 \\
\hline & Contractor & 28 & 4.11 & 0.567 \\
\hline & Total & 108 & 4.04 & 0.819 \\
\hline \multirow{4}{*}{$\begin{array}{l}\text { d) Improper decision support system for } \\
\text { contractor's evaluation }\end{array}$} & Client & 58 & 3.84 & 1.040 \\
\hline & Consultant & 22 & 4.00 & 0.617 \\
\hline & Contractor & 28 & 4.18 & 0.670 \\
\hline & Total & 108 & 3.96 & 0.885 \\
\hline \multirow{4}{*}{$\begin{array}{l}\text { Several problems in the tendering phase } \\
\text { are occurring in public projects because } \\
\text { of ignoring standard procurement } \\
\text { guidelines. }\end{array}$} & Client & 58 & 3.84 & 0.933 \\
\hline & Consultant & 23 & 3.96 & 0.638 \\
\hline & Contractor & 28 & 4.14 & 0.448 \\
\hline & Total & 109 & 3.94 & 0.780 \\
\hline \multirow{4}{*}{$\begin{array}{l}\text { Contractors are not properly evaluated } \\
\text { because of insufficient quality criteria set } \\
\text { by organizations. }\end{array}$} & Client & 58 & 3.81 & 0.888 \\
\hline & Consultant & 23 & 4.04 & 0.638 \\
\hline & Contractor & 28 & 4.04 & 0.429 \\
\hline & Total & 109 & 3.92 & 0.747 \\
\hline \multirow{4}{*}{$\begin{array}{l}\text { Clients are facing an issue of getting } \\
\text { incorrect information on qualification } \\
\text { criteria from contractors. }\end{array}$} & Client & 58 & 3.95 & 0.981 \\
\hline & Consultant & 23 & 3.91 & 0.793 \\
\hline & Contractor & 28 & 3.61 & 0.786 \\
\hline & Total & 109 & 3.85 & 0.901 \\
\hline \multirow{4}{*}{$\begin{array}{l}\text { Contractor's evaluation is becoming } \\
\text { difficult due to the absence of proper } \\
\text { screening at an early stage. }\end{array}$} & Client & 58 & 4.00 & 1.009 \\
\hline & Consultant & 23 & 4.04 & 0.767 \\
\hline & Contractor & 28 & 4.04 & 0.881 \\
\hline & Total & 109 & 4.02 & 0.923 \\
\hline \multirow{4}{*}{$\begin{array}{l}\text { The client must consider proper threshold } \\
\text { marks (minimum passing marks) during } \\
\text { prequalification. }\end{array}$} & Client & 58 & 4.26 & 0.762 \\
\hline & Consultant & 23 & 4.39 & 0.583 \\
\hline & Contractor & 28 & 4.18 & 0.548 \\
\hline & Total & 109 & 4.27 & 0.676 \\
\hline \multirow{4}{*}{$\begin{array}{l}\text { Capable contractors are not selected } \\
\text { because of improper weightages are } \\
\text { given to cost in comparison to other } \\
\text { qualification criteria. }\end{array}$} & Client & 58 & 3.97 & 1.092 \\
\hline & Consultant & 23 & 4.22 & 0.736 \\
\hline & Contractor & 28 & 4.32 & 0.548 \\
\hline & Total & 109 & 4.11 & 0.916 \\
\hline \multirow{4}{*}{$\begin{array}{l}\text { A more capable contractor can be } \\
\text { selected if technical parameters are given } \\
\text { high importance/weightage. }\end{array}$} & Client & 58 & 4.52 & 0.628 \\
\hline & Consultant & 23 & 4.26 & 0.689 \\
\hline & Contractor & 28 & 4.21 & 0.686 \\
\hline & Total & 109 & 4.39 & 0.665 \\
\hline
\end{tabular}


Table 3 (continue)

\begin{tabular}{|c|c|c|c|c|}
\hline Suggestions & Type of respondents & $\mathrm{N}$ & Mean & Std. Deviation \\
\hline \multirow{4}{*}{$\begin{array}{l}\text { The contractor assessment process } \\
\text { can be improved if the benefits of } \\
\text { prequalification or technical phase are } \\
\text { given in the final contract award. }\end{array}$} & Client & 58 & 4.45 & 0.776 \\
\hline & Consultant & 23 & 3.87 & 0.869 \\
\hline & Contractor & 28 & 4.43 & 0.573 \\
\hline & Total & 109 & 4.32 & 0.780 \\
\hline \multirow{4}{*}{$\begin{array}{l}\text { The lowest bid award system in public } \\
\text { project is responsible for several mishaps } \\
\text { in any project. }\end{array}$} & Client & 58 & 4.36 & 0.742 \\
\hline & Consultant & 23 & 4.17 & 0.778 \\
\hline & Contractor & 28 & 4.43 & 0.504 \\
\hline & Total & 109 & 4.34 & 0.697 \\
\hline \multirow{4}{*}{$\begin{array}{l}\text { Other than price-based selection method } \\
\text { must be developed in Pakistan. }\end{array}$} & Client & 58 & 4.48 & 0.504 \\
\hline & Consultant & 23 & 4.35 & 0.487 \\
\hline & Contractor & 28 & 4.32 & 0.670 \\
\hline & Total & 109 & 4.41 & 0.548 \\
\hline \multirow{4}{*}{$\begin{array}{l}\text { Contractors must be given flexibility in } \\
\text { bid price quotation within the ceiling } \\
\text { price limit. }\end{array}$} & Client & 58 & 4.03 & 0.837 \\
\hline & Consultant & 23 & 4.13 & 0.548 \\
\hline & Contractor & 28 & 4.36 & 0.559 \\
\hline & Total & 109 & 4.14 & 0.726 \\
\hline \multirow{4}{*}{$\begin{array}{l}\text { The client should accept any bid lies } \\
\text { within the limit of ceiling price to make } \\
\text { process more flexible. }\end{array}$} & Client & 58 & 4.02 & 0.827 \\
\hline & Consultant & 23 & 3.96 & 0.825 \\
\hline & Contractor & 28 & 4.36 & 0.678 \\
\hline & Total & 109 & 4.09 & 0.800 \\
\hline \multirow{4}{*}{$\begin{array}{l}\text { Public projects are suffering several } \\
\text { problems because of poor mechanism of } \\
\text { public tendering. }\end{array}$} & Client & 58 & 3.90 & 1.003 \\
\hline & Consultant & 23 & 3.96 & 0.878 \\
\hline & Contractor & 28 & 4.14 & 0.591 \\
\hline & Total & 109 & 3.97 & 0.887 \\
\hline \multirow{4}{*}{$\begin{array}{l}\text { Contractor selection issues are pertaining } \\
\text { because of improper traditional } \\
\text { contractor's assessment system. }\end{array}$} & Client & 58 & 4.05 & 0.944 \\
\hline & Consultant & 23 & 4.04 & 0.878 \\
\hline & Contractor & 28 & 4.11 & 0.497 \\
\hline & Total & 109 & 4.06 & 0.831 \\
\hline \multirow{4}{*}{$\begin{array}{l}\text { The human-based assessment system } \\
\text { causing problems in contractors' } \\
\text { selection process. }\end{array}$} & Client & 58 & 3.60 & 0.972 \\
\hline & Consultant & 23 & 3.83 & 1.154 \\
\hline & Contractor & 28 & 4.25 & 0.752 \\
\hline & Total & 109 & 3.82 & 0.992 \\
\hline \multirow{4}{*}{$\begin{array}{l}\text { Contractor's assessment system during } \\
\text { the evaluation phase can help in smooth } \\
\text { and justified assessments. }\end{array}$} & Client & 58 & 4.14 & 0.712 \\
\hline & Consultant & 23 & 3.96 & 0.562 \\
\hline & Contractor & 28 & 4.21 & 0.418 \\
\hline & Total & 109 & 4.12 & 0.620 \\
\hline \multirow{4}{*}{$\begin{array}{l}\text { The complexity of the tendering process } \\
\text { can be minimized with the help of } \\
\text { automated decision-making system. }\end{array}$} & Client & 58 & 3.97 & 1.008 \\
\hline & Consultant & 23 & 3.74 & 1.054 \\
\hline & Contractor & 28 & 4.04 & 0.637 \\
\hline & Total & 109 & 3.94 & 0.936 \\
\hline
\end{tabular}


confirms that an extensive assessment of contractors is needed of the hour in construction sector in Pakistan. Further examination reveals that no doubt clients, consultants, and contractors are key personnel of a project, but the project accomplishment is more reliant upon the shoulders of a contractor in Pakistan. These results are in accordance with many past studies such as Alzahrani and Emsley (2013), and Lundberg and Bergman (2017), who believed that performance of project was highly dependent on the shoulders of contractors. In this continuation, furthermore, impressive results were found. According to the results, in Pakistan, mostly public projects fail because of selecting incapable contractors. Results confirm that the significance of selecting capable contractor for a public project is still not taken seriously. Apart from the capable contractor selection, owing to several governmental formalities as the funds belong to the public, public tendering is believed to be more complicated than its private counterpart projects bidding. Survey results found that the private sector is relatively more straightforward in process. The public tendering is bounded in more legal formalities and procedures. This is owing to a large number of formalities in public tendering; a higher number of requirements are asked from the contractors that are making the process obscure. Lundberg and Bergman (2017) also confirmed that public tendering complexity resulted in a lesser quality project compared to its private counterpart. The results also confirmed findings from the studies of Judit (2017) and Long et al. (2004). This leads to the suggestion that an easier and straightforward process with lesser formalities needs to be designed to get rid of various inherent issues of public tendering.

Several other problems tend to persist from the evaluation of contractors until its final award that is based on price. Referring to the survey results, the problematic evaluation process of contractors is to be blamed for project failures in the country. Several complications happened when wrong contractors entered the bidding and being awarded the project. Liu et al. (2015) assumed that a contractor whose capabilities did not match the project requirement creates problems of time, cost, and quality in project later on. Ultimately, the end goal of every client is to have a successful end to projects where a contractor plays a major role (Watt et al., 2010). Further reasons for project failure in the context of public tendering were reported as; "lowest bid price selection" which was discussed earlier. These results are consistent with the earlier findings of Cheaitou et al. (2019) and Zhang et al. (2015). Exploration of results further divulges that public clients are ignoring the standard procurement guidelines while designing, evaluating, and awarding the tenders. The survey found that the issue is most prevailing in the country, and experts believe this is one of the major causes of public tendering failure. Therefore, it is suggested that the lowest bid system is abolished. This can further be improved through extensive contractor's evaluation before the bid stage. In this regard, an effective tool can be a standard procurement guideline. The second most critical reason of project failure was found as "insufficient contractor's technical evaluation," and the other similar causes 
were stated as "poor weightage consideration of technical and bid price" and "improper decision support system for contractor's evaluation."

Proper evaluation of contractors is still a dominant issue in Pakistan as reported in the survey. Incapable contractors often became part of the competition owing to insufficient criteria set by the organizations. The study indicated that the existing evaluation criteria (Experience, Financial Soundness, Technical Personnel, Equipment, Management Capability, Quality and Health \& Safety) received very high critics. Patil (2017) also, believed that proper screening in terms of evaluation criteria was necessary. Apart from the issues of insufficient criteria, designing and keeping the ambiguous criteria is another subject of matter where correct information from contractors is challenging to obtain is another subject of matter. Furthermore, results have proven that in the evaluation process, clients did not get accurate information from the contractors and this was due to improper designing of quality criteria. According to the survey results, due to the deficiency of proper screening, the contractor's evaluation has become problematic. The experts believed that appropriate screening criteria in the preliminary phase can decrease more burdensome participation in the evaluation stage. Thus, this leads to the design of an extensive set of tougher criteria for initial scrutiny of contractors with higher weight on technical parameters over the cost. The results are in accordance with the assertion of Lundberg $\&$ Bergman (2017) who believed that quality parameters must be weighted more than cost considerations if the quality was ultimate expectations from the outcome.

As discussed above, the role of threshold marks is only limited to technical assessment phase (or prequalification stage) only. In this regard, many experts and professionals believed that proper calculation of threshold marks is not considered anywhere in public tendering practice. Henceforth, they believe that the proper understanding of such marks must be incorporated. The experts believe that the contractor's assessment process can be improved further if the contractors are given the benefits of their higher marks in the final award of work. This suggests that certain percentages of technical phase process must be kept for the final award. This can offer the equal opportunity to a contractor for wining a project who will quote a right bid price over the least bid.

While addressing the issues to get rid of the lowest bid award system in Pakistan, the survey found interesting results. From the survey results, it was revealed that the lowest bid price selection is causing the problem in public projects and alternative to the price-based methods are grievously needed to be designed respectively. Zhang et al. (2015) also stressed that evaluation of bid was a significant concern in public tendering. This is also according to the study by Mamavi et al. (2017) which claims that apart from reality, several basic models of bid evaluation suggest that cost should not be the parameters for contractor selection. The problem of lowest bid selection can be resolved with an alternative suggestion. It is 
suggested that contractors are offered flexibility while quoting their bid within the ceiling price limit. Clients are recommended to accept any bid from the contractors that is within the upper limit of ceiling price irrespective of the lowest value in the competition. This situation would not create any problem of over utilizing public funds and would further enhance the chances of fair competitions. The contractors will also be given their due right in the form of sufficient return on its investment. Therefore, the chances of providing bad quality outcome can also be minimized.

The long-lasting issues in public tendering in Pakistan are the results of certain traditional practices. Moreover, the human-based assessment system has created many flaws in the form of unjustified decisions and biases in the assessment process. Based on the survey, it was found that the tendering process in Pakistan is largely affected by traditional customs and human-based assessment. The absence of more objective evaluation led to unjustified decisions and biases in assessment processes. Thus, an assessment for the purpose of selecting contractors for public projects in Pakistan requires serious attention and more objective approach is needed. Nowadays, the world has entered the era of modernization, where the use of advanced tools and techniques is within reach for everyone. Unfortunately, the tendering department in many organizations in Pakistan are still in its old-fashioned way. This is especially so in the contractor's assessment system where a person or a team decides on the future of contractors with no or fewer means of alternative modern assessment methods or techniques, and with and with no guarantee of precision. The data analysis of respondents suggested that an automated decision support system can be a helpful tool in public organizations. Respondents agreed that such a system, if developed, could further simplify one of the difficult phases of public tendering i.e. justified assessment. Furthermore, they decided that many difficulties arising during the assessment process that is a hurdle in equal treatment of the contractors could be minimized with the system. With the aforementioned discussions on opinion on present practices and their solution in the form recommendations, a theoretical framework is developed to pave a road map for public tendering.

\section{Public Tendering Theoretical Outcome for Pakistan Construction Projects}

Referring to the research questions raised in the beginning, the exhaustive survey propagates in three different directions i.e. issues, practices, and recommendations in public tendering in Pakistan. In the first part i.e. current practices of public tendering in Pakistan, the issues and practices are investigated. The third direction of recommendations is computed from the second part of survey. Therefore, the results obtained from the analysis propagates in three different directions and helped in the development of theoretical framework. The novel research contribution is thus achieved in this research that can fill the wide gaps in current body of knowledge (Figure 2). 
Figure 2 exemplifies that several ill practices in public projects in Pakistan are prevailing. These outdated customs of tendering process are a key hindrance in the development of the industry. The theoretical outcome interlinked each ill designed process to current issues facing the industry. Several inherent issues are emphasized that are the outcome of poor practices in Pakistan. Following up the issues, industry experts were called for their suggestions. Experts emphasized on various helpful recommendations those are mentioned under the analysis and discussion section. The recommendations are linked with each case of practices and issues and illustrated in Figure 2. The theoretical outcome of public tendering is a blueprint in construction sector. The recommendations drawn in the

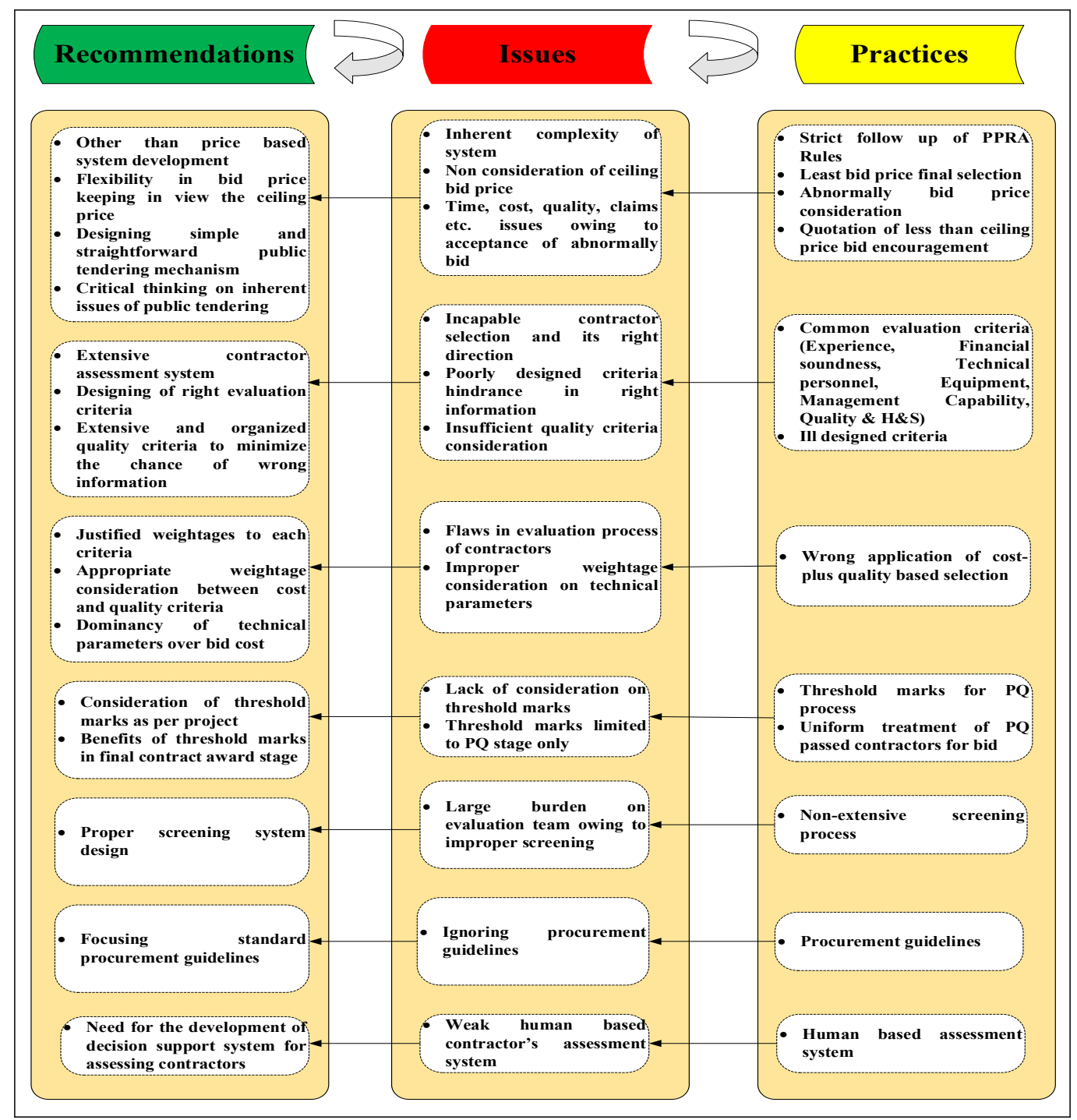

Figure 2. Public tendering theoretical outcome for Pakistan construction projects 
end are fruitful in filling the wide gaps and pitfalls for public sector in Pakistan. Especially, a critical thought is required to overcome the issues of human assessment system that received a lot of critics. Construction sector in Pakistan is suggested to strictly follow the outcome for a better and prosperous construction sector.

\section{CONCLUSION AND RECOMMENDATION}

Public tendering in Pakistan is still at the embryonic stage. Exhaustive research was carried out to ascertain the current practices in public tendering and expert opinion on current issues of public tendering in Pakistan and various recommendations are put forward. A one-way ANOVA test clarified the divergence in the opinion of different stakeholders. Henceforth null hypothesis formulated in the beginning is rejected based on sig. values obtained in the one-way ANOVA test. The study results revealed several threatening results on a ground reality basis. The study concludes that in Pakistan, construction projects are turning into a modern phase and contractors are not capable enough to confront to meet the demands of new challenges. This has resulted in the failure of several projects in Pakistan. Further results revealed that a capable contractor selection is still an unresolved issue of public tendering. This is because the quality criteria on which contractors were assessed are not enough and not correctly designed. Also, a proper weightage on quality criteria and cost is not developed yet, leading to incapable contractor selection.

Furthermore, contractors passing the prequalification criteria are treated equally, which is not in favor of the system. Currently, clients are not interested in redesigning the threshold marks that would result in severe negative outcome soon. Several such reasons are responsible for complexity in public tendering comparing to the private sector. Many alarming results were obtained on bid price selection also. For instance, in Pakistan, the concept of accepting abnormal bid is prevailing and the clients offer the project to one who quotes the least bid price, dodging the clauses of PPRA. This system is believed to be a significant failure of public projects. The study concludes that competent contractor is vital in undertaking projects especially to cope with the advancement of technology and the complex nature of nowadays project. As such rigorous criteria must be included in the assessment stage to truly reflect the capacity and the capability of the contractor. In addition to this, decision making should be aided by automated decision making which will help to eliminate the biasness created in the human-judgement as per current practices in Pakistan. The study ends up with a theoretical outcome for public sector that is a novel contribution in the current knowledge. This study calls for exploring detailed project case studies to validate the findings further. Moreover, it recommends developing a decision support model for improving the current flaws in public tendering in Pakistan. 


\section{ACKNOWLEDGMENT}

All praise to Almighty God, without His support, we would not be able to write a single sentence.

\section{REFERENCES}

Alzahrani, J. I., \& Emsley, M. W. (2013). The impact of contractors' attributes on construction project success: A post construction evaluation. International Journal of Project Management, 31(2), 313-322. doi: https:// doi.org/10.1016/j.ijproman.2012.06.006

Ayoti, B. (2012). Factors influencing effectiveness in tendering process in public sector; The case of Nyeri County, Kenya (Doctoral dissertation). University of Nairobi, Kenya.

Azhar, N., Farooqui, R. U., \& Ahmed, S. M. (2008, August 4-5). Cost overrun factors in construction industry of Pakistan. In First International Conference on Construction in Developing Countries (ICCIDC-I), Advancing and Integrating Construction Education, Research \& Practice (pp. 499-508). Karachi, Pakistan.

Birjandi, A. K., Akhyani, F., Sheikh, R., \& Sana, S. S. (2019). Evaluation and selecting the contractor in bidding with incomplete information using MCGDM method. Soft Computing, 23(20), 10569-10585. doi: https:// doi.org/10.1007/s00500-019-04050-y

Bochenek, J. (2014). The contractor selection criteria in open and restricted procedures in public sector in selected EU countries. Procedia Engineering, 85, 69-74. doi: https://doi.org/10.1016/j.proeng.2014.10.530

Cheaitou, A., Larbi, R., \& Al-Housani, B. (2019). Decision making framework for tender evaluation and contractor selection in public organizations with risk considerations. Socio-Economic Planning Sciences, 68(January 2017), 1-12. doi: https://doi.org/10.1016/j.seps.2018.02.007

Elsayah, O. S. (2016). A framework for improvement of contractor selection procedures on major construction project in Libya. Retrieved October 27, 2018, from https:/www.napier.ac.uk/ /media/worktribe/output453191/a-framework-for-improvement-of-contractor-selection.pdf

Farooqui, R. U., Saqib, M., Arif, F., \& Lodi, S. H. (2008, August 4-5). An assesment of general trends adopted for bidding and procurement in the construction indystry of Pakistan. In First International Conference on Construction In Developing Countries (ICCIDC-I) "Advancing and Integrating Construction Education, Research \& Practice” (pp. 153-160). Karachi, Pakistan.

Hochstetter, J., Cachero, C., Cares, C., \& Sepúlveda, S. (2004). Call for tenders challenges in practice: A field study. Retrieved January 27, 2019, from http:/www.inf.puc-rio.br/ cibse/CIBSEPapers/artigos/ artigos_CIBSE12/paper_60.pdf

Horat, I. M., Camanho, A. S., \& Lima, A. F. (2013). Design of performance assessment system for selection of contractors in construction industry E-marketplaces. Journal of Construction Engineering and Management, 139(8), 910-917. doi: https://doi.org/10.1061/(ASCE)CO.1943-7862.0000691

Ibrahim, M., Bawole, J. N., Obuobisa-Darko, T., Abubakar, A. B., \& Kumasey, A. S. (2017). The legal regime and the compliance façade in public procurement in Ghana. International Journal of Public Sector Management, 30(4), 370-390. doi: https://doi.org/10.1108/IJPSM-09-2016-0156 
Jaskowski, P., Biruk, S., \& Bucon, R. (2009). Assessing contractor selection criteria weights with fuzzy AHP method application in group decision environment. Automation in Construction, 19, 120-126. doi: https:// doi.org/10.1016/j.autcon.2009.12.014

Jobling, P. E., \& Smith, N. J. (2018). Experience of the role of contracts in megaproject execution. Proceedings of the Institution of Civil Engineers-Management, Procurement and Law, 171(1), 18-24. doi: https://doi. org/10.1680/jmapl.17.00006

Judit, S. (2017, November 8-10). Days of EU law. In Proceedings of the International Scientific Conference (pp. 76-85). Győr, Hungary.

Kadefors, A. (2005). Fairness in interorganizational project relations: Norms and strategies. Construction Management and Economics, 23(8), 871-878. doi: https://doi.org/10.1080/01446190500184238

Khan, T. H., \& Khan, A. Q. (2015). Effects of lowest bidding bid awarding system in public sector construction projects in Pakistan. Developing Country Sudies, 5(3), 132-147.

Khoso, A. R., \& Yusof, A. M. (2020). Extended review of contractor selection in construction projects. Canadian Journal of Civil Engineering, 47(7), 771-789. doi: https://doi.org/10.1139/cjce-2019-0258

Kim, S. Y., Tuan, N. K., Lee, J. D., Pham, H., \& Luu, V. T. (2018). Cost overrun factor analysis for hospital projects in Vietnam. KSCE Journal of Civil Engineering, 22(1), 1-11. doi: https://doi.org/10.1007/ s12205-017-0947-5

Kog, F., \& Yaman, H. (2016). A multi-agent systems-based contractor pre-qualification model. Engineering, Construction and Architectural Management, 23(6), 709-726. doi: https://doi.org/10.1108/ECAM-012016-0013

Kog, F., Yaman, H., \& Kog, F., \& Yaman, H. (2014). A meta classification and analysis of contractor selection and prequalification. Procedia Engineering, 84,302-310. doi: https://doi.org/10.1016/j.proeng.2014.10.555

Kumaraswamy, M. M., \& Anvuur, A. M. (2008). Selecting sustainable teams for PPP projects. Building and Environment, 43, 999-1009. doi: https://doi.org/10.1016/j.buildenv.2007.02.001

Liu, B., Huo, T., Meng, J., Gong, J., Shen, Q., \& Sun, T. (2015). Identification of key contractor characteristic factors that affect project success under different project delivery systems. Journal of Management in Engineering, 32(1), 1-11. doi: https://doi.org/10.1061/(ASCE)ME.1943-5479.0000388

Long, N. D., Ogunlana, S., Quang, T., \& Lam, K. C. (2004). Large construction projects in developing countries: A case study from Vietnam. International Journal of Project Management, 22(7), 553-561. doi: https:// doi.org/10.1016/j.ijproman.2004.03.004

Lo, W., Lin, C. L., \& Yan, M. R. (2007). Contractor's opportunistic bidding behavior and equilibrium price level in the construction market. Journal of Construction Engineering and Management, 133(6), 409-416. doi: https://doi.org/http://dx.doi.org/10.1061/(ASCE)07339364(2007)133:6(409)

Lo, W., \& Yan, M. R. (2009). Evaluating qualification-based selection system. Journal of Construction Engineering and Management, 135(6), 458-465. doi: https://doi.org/https://doi.org/10.1061/(ASCE) CO.1943-7862.0000013

Lundberg, S., \& Bergman, M. A. (2017). Tendering design when price and quality is uncertain. International Journal of Public Sector Management, 30(4), 310-327. doi: https://doi.org/10.1108/IJPSM-04-2016-0063 
Mamavi, O., Meier, O., \& Zerbib, R. (2017). How do strategic networks influence awarding contract? Evidence from French public procurement. International Journal of Public Sector Management, 30(4), 357-369. doi: https://doi.org/10.1108/IJPSM-05-2016-0091

Maqsoom, A., Charoenngam, C., Masood, R., \& Awais, M. (2014). Foreign market entry considerations of emerging economy firms: An example of Pakistani contractors. Procedia Engineering, 77, 222-228. doi: https://doi.org/10.1016/j.proeng.2014.07.020

Melody, A. H. (2008). Considerations in determining sample size for pilot studies. Research in Nursing and Health, 31(2), 180-191. doi: https://doi.org/10.1002/nur.20247

Morenikeji, W. (2006). Research and analytical methods for social scientist, planners and environmentalist (1st Ed.). Jos, Nigeria: Jos University Press Ltd.

Murtagh, S. R., \& Brooks, T. (2019). Critical success factors for social value in construction procurement in Northern Ireland. Proceedings of the Institution of Civil Engineers-Management, Procurement and Law, 172(5), 183-196. doi: https://doi.org/10.1680/jmapl.19.00005

Ng, S. T., \& Skitmore, R. M. (2001). Contractor selection criteria: A cost-benefit analysis. IEEE Transactions on Engineering Management, 48(1), 96-106. doi: https://doi.org/10.1109/17.913169

Ng, S. T., Tang, Z., \& Palaneeswaran, E. (2009). Factors contributing to the success of equipment-intensive subcontractors in construction. International Journal of Project Management, 27(7), 736-744. doi: https:// doi.org/10.1016/j.ijproman.2008.09.006

Patil, K. (2017). Public procurement policy for small and medium enterprises in developing countries: Evidence from India. International Journal of Public Sector Management, 30(4), 391-410. doi: https:// doi.org/10.1108/IJPSM-10-2016-0160

Phogat, S., \& Gupta, A. K. (2019). Evaluating the elements of just in time (JIT) for implementation in maintenance by exploratory and confirmatory factor analysis. International Journal of Quality and Reliability Management, 36(1), 7-24. doi: https://doi.org/10.1108/IJQRM-12-2017-0279

PPRA. (2015). Annual report 2014-15-public procurement regulatory authority. Retrieved May 13, 2020, from https://www.ppra.org.pk/areports.asp

Wahlberg, A. E., \& Poom, L. (2015). An empirical test of nonresponse bias in internet surveys. Basic and Applied Social Psychology, 37(6), 336-347. doi: https://doi.org/10.1080/01973533.2015.1111212

Wang, J., Yu, B., Tam, V. W. Y., Li, J., \& Xu, X. (2019). Critical factors affecting willingness of design units towards construction waste minimization: An empirical study in Shenzhen, China. Journal of Cleaner Production, 221, 526-535. doi: https://doi.org/10.1016/j.jclepro.2019.02.253

Watt, D. J., Kayis, B., \& Willey, K. (2010). The relative importance of tender evaluation and contractor selection criteria. International Journal of Project Management, 28(1), 51-60. doi: https://doi.org/10.1016/j. ijproman.2009.04.003

Wondimu, P. A., Klakegg, O. J., Lohne, J., \& Lædre, O. (2020). Experiences with best-value procurement in Norway and the Netherlands. Journal of Construction Engineering and Management, 146(5), 1-13. doi: https://doi.org/10.1061/(ASCE)CO.1943-7862.0001814 
Wong, C. H., Holt, G. D., \& Cooper, P. A. (2000). Lowest price or value? Investigation of UK construction clients' tender selection process. Construction Management and Economics, 18(7), 767-774. doi: https:// doi.org/10.1080/014461900433050

Zhang, Y., Luo, H., \& He, Y. (2015). A system for tender price evaluation of construction project based on big data. Procedia Engineering, 123, 606-614. doi: https://doi.org/10.1016/j.proeng.2015.10.114 
